\title{
Reducing Hate and Prejudice on Campus: A Sociologist's Contributions ${ }^{1}$
}

\author{
Jack Levin $^{2}$
}

[Article copies available for a fee from The Transformative Studies Institute.E-mail address: journal@transformativestudies.org Website: http://www.transformativestudies.org (02011 by The Transformative Studies Institute. All rights reserved.]

Our educational institutions are, for good reason, generally regarded as bastions of enlightenment and respect for diversity. Indeed, students on most campuses are exposed to a broad range of ideas, speakers, faculty members, and fellow students. They are encouraged to express dissenting points of view and to interact with diverse fellow students and faculty members. They might work or study in other countries, or do community service among diverse populations.

Yet our image of the college experience may also underestimate seriously the intergroup hostility and conflict that, on occasion, can come to define relationships on a campus. In a highly competitive environment, where students vie for grades, scholarships, jobs, organizational budgets, and popularity, they may regard one another not as allies but as opponents competing for scarce resources. In one recent survey of 10

\footnotetext{
${ }^{1}$ Jack Levin, Sociologists in Action pp. 90-95, copyright 2011 by Pine Forge Press, Reprinted by Permission of Pine Forge Inc.

${ }^{2}$ Jack Levin, Ph.D., is the Brudnick Professor of Sociology and Criminology at Northeastern University in Boston, where he codirects its Center on Violence and Conflict. He has authored or coauthored 30 books, including The Violence of Hate: Confronting Racism, Anti-Semitism, and Other Forms of Bigotry ( $3^{\text {rd }}$ ed., 2010, with Jim Nolan). Levin recently received a major award from the American Sociological Association for his efforts to increase the public understanding of sociology. He has spoken to a wide variety of community, academic, and professional groups, including the White House Conference on Hate Crimes, the Department of Justice, the Department of Education, the Organization for Security and Co-operation in Europe's Office for Democratic Institutions and Human Rights (with a membership of 59 countries), the National Association of Hostage Negotiators, and the International Association of Chiefs of Police.
} 